\title{
COMPARATIVE DISCOURSE ANALYSIS ON MEDIA RELATED TWEETS OF PRESIDENT DONALD TRUMP AND SENATOR BERNIE SANDERS
}

\author{
Hülya Ünsal Şakiroğlu \\ Kafkas University, \\ School of Foreign Languages, \\ Kars, Turkey
}

\begin{abstract}
:
This study aims to investigate the language and the attitude of two well-known U.S. politicians, U.S. President Donald Trump and Bernie Sanders, towards media in their social media messages on Twitter microblogging site. The comparison and analyses are performed using Fairclough's analytical framework of the socio-cultural approach of Critical Discourse Analysis (CDA): text, discourse practice, and sociocultural practice. The data consists of 50 non repetitive recent media related tweets collected from personal accounts of Trump and Sanders. The findings indicate that Trump uses an informal, direct, and provoking communication style to construct and reinforce the concept of a homogeneous people and a homeland threatened by the dangerous and biased other (media) while Sanders having more democratic, liberal language, and focuses on more tangible, important social issues such as environment, education, and health problems as he himself prominences often. Moreover, Trump employs positive self-presentation and negative other presentation to further promote his agenda via social media. Bernie Sanders on the other hand criticize media for a set of different reasons. Although they both criticize the media extensively in their usage of Twitter, discourse analyses indicate that the underlying political motivations are fundamentally different.
\end{abstract}

Keywords: critical discourse analysis, media, tweets, Trump, Sanders

\section{Introduction}

As it is the case for all the business groups, contemporary media is organized around a global network of multi-media corporations. The corporatizing is extended to large national and regional companies and even further to their local affiliates in different areas of the world (Arsenault and Castells, 2008; Bennett, 2004). This vast corporatization has raised flags regarding media and news coverage all around the globe.

There has been a global right-wing populism and extremism in politics (Wodak, 2015). Although a number of opposite movement has recently upraised, the general heavy rightwing dominance is still a global phenomenon (Wodak, 2015). On the other hand, there is an opposite

i Correspondence: email hulyaunsal@kafkas.edu.tr 
discourse gaining popularity using anti-corporate rhetoric. Questioning of the regulatory structures and morality of global capitalism based on the multinational companies, concerns have raised regarding corporate social responsibility (CSR) and corporate citizenship (Burchell and Cook, 2006).

The social media usage has increased geometrically in the past few years around the globe and this growth has been evaluated in scientific reports (Wigand, Wood, and Mande, 2010). The social media has provided the opportunity to locate, organize, and coordinate groups of individuals with similar interests. In addition, the social media has dramatically changed news sources, and the ability to solicit and share opinions and ideas virtually in any topic to a wider audience instantaneously (Stieglitz and Dang-Xuan, 2013). Therefore, the politicians all over the world has discovered this new communication channel and have been using it extensively (Grant, Moon, and Busby Grant, 2010; Larsson and Kalsnes, 2014).

Nevertheless, the widespread use of social media has created new framework for the relationship between journalists and politicians and between news media and politics (Ekman and Widholm, 2015). As this implies a new set of power relations between journalism and politics, media and politicians have become both actors and sources through mutual interaction in online spaces (Ekman and Widholm, 2015). It will not be surprising that media will benefit from the new framework as there is a wealth of material at their dispose. However, politicians will enjoy getting their media related messages to broader audience without dependency to the traditional media.

President of the United States, Donald Trump and Presidential Candidate and Vermont senator Bernie Sanders were political rivals for US presidential election and representing two social, ideological poles of contemporary US politics. Donald Trump was the candidate and is still affiliated with the Republican Party whereas Bernie Sanders represent the most progressive political lineage of the Democratic Party. This rivalry along with the extended agenda receives a massive global interest as it implies a major global power distribution between the longstanding ideological poles. Both politicians are disseminating their political message in social media widely. Twitter is the main social media channel for both Trump and Sanders. Trump has 60.4 million followers whereas Sanders is followed by 8.35 million on Twitter platform (as of March 2020). It is not surprising that the discourse of U.S. President Donald Trump is heavily dominated with the extreme right rhetoric (Ott, 2017) and Sanders is emphasizing a social democratic values in his tweets.

In the present work, I used the Critical Discourse Analysis (CDA) and Socio-cultural approach to evaluate media related tweets of the two opposing and rivalry prominent politicians in US.

\section{Discourse and discourse analysis}

The definitions of "discourse" and "discourse analysis" have different meanings to scholars majoring in variety of fields. For linguists, for instance "discourse" has generally been defined as anything "beyond the sentence." Jaworski and Coupland (1999) include 10 definitions from a wide range of sources. They all, however, fall into the three main categories: (1) anything beyond 
the sentence, (2) language use, and (3) a broader range of social practice that includes nonlinguistic and non-specific instances of language (Schiffrin, Tannen, \& Hamilton, 2015).

Discourse analysis, on the other hand, is described as the study of language in use and meanings given to language. The actions are carried out when language is used in specific contexts. It is also defined as the study of language above the level of a sentence to create meaning, coherence, and accomplish purposes. The phrase "discourse analysis" refers to the study of how the sentences in a text or talk create meaning and coherence (Gee and Handford, 2012).

Critical discourse analysis (CDA) is the study of the way social-power abuse and inequality are enacted, reproduced, legitimated, and resisted by text and talk mainly in the social and political context. Critical discourse analysts take an explicit position to change social inequality. The general properties of critical research on discourse are focusing primarily on social problems and political issues which are multidisciplinary rather than the mere study of discourse structures, describing and also explaining discourse structures, focusing on the ways how discourse structures enact, confirm, legitimate, reproduce, or challenge relations of power abuse in society (Van Dijk, 1993).

Media discourse has inspired many critical studies in many disciplines, not least in the field of mass communication but also linguistics, semiotics, pragmatics, and discourse studies. Media discourse analysis starts with observable surface structures of biased or partisan use of words in the description of "Us/Them" and "Our/Their" actions characteristics, especially along socio-political lines. It subsequently evolves to the studies on critical literature of popular culture and the media. Critical media studies focus less on discourse structures. Among the most widely used subjects have been the media representations of women (feminist discourse) and minorities, the analysis of biased, stereotypical- sexist or racist images in the media, both in text and illustrations and photos. The critical media studies pay attention to photos, interviews, minority news, international news, gender, racism in the press, crime news etc. and critically asses subtle bias of the official media (Van Dijk, 2001). Media discourse refers to interactions that take place through a broadcast platform, whether spoken or written, in which the discourse is directed to a non-present reader, listener or viewer. Since the discourse directed to those recipients, the producers of discourse most often do not provide immediate responses, but with the emergence of digital media technologies, this increasingly changes ( $\mathrm{O}^{\prime}$ keeffe, 2011).

Political discourse involves formal / informal political contexts and political actors (i.e., politicians, political institutions, governments, political media and political supporters employed in political environments to achieve political objectives, among others) (Wilson, 2003). It could have many areas of interest such as analysis of politicians and military, the metaphor in foreign policy, the discourse of war and political conflict (Chilton, 2004). How political speech is reported what the role of context in speech reporting is, how verbs denoting speech may imply positive/negative affect, low/high volatility is some other topics included in political discourse. The use of pronouns such as I-We and their implied group of reference, inclusion, exclusion and allegiances. Communication in the organizations, language barriers in courtroom, schools and hospitals, sexism in language, antisemitism, racism and the images of enemy are other significant areas that have been studied (Van Dijk, 2001). Political discourse analysis, however, is an approach explores how movement actors seek to question existing conceptions of political reality 
by mobilizing new perceptions of disputed social relationships -schemes, frames - and making them visible in the public domain (Koopmans and Statham, 1999).

\section{Critical Linguistics and Critical Discourse Approach}

Critical linguistics and critical discourse approach are an interdisciplinary approach that includes multiple perspectives. This approach is more problem delineation oriented than elaboration of the specific linguistic elements. Complex social problems are research articles on a wide range of problem areas such as racism and social change. The theories and methods which are sufficient to understand and explain the object are integrated. The study usually involves a field study and ethnography as a prerequisite for further analysis and theory to explore the object being studied. Historical and wider socio-political contexts are analyzed and integrated into the interpretation of discourses and texts. The categories and tools for analysis are identified by a specific problem in accordance with all these steps and subsequently investigated in the critical approach (Zienkowski et al., 2011).

\subsection{Systemic functional linguistics}

Systemic functional linguistics perceives the language as a semiotic instrument in the negotiation, construction, organization and reconstruction of human experience. The approach shows how language choices systematically contribute to the realization of social contexts. In this understanding, language exceeds the boundary of a meaning channel and becomes the basic resource for meaning. It is also a part of reality, a form of reality, and a metaphor of reality (Fang, 2005).

\subsection{Social semiotics}

Social semiotics emphasizes the relationship between the grammar system and the social and personal needs required to serve that language. Halliday distinguished the meta-function of three interdependent languages: (1) the ideational function which lends to experience the structure of the language. It is the experience of the worlds and phenomena of speakers. The structure of thought has a dialectical relationship with the social structure that reflects and affects it. (2) Interpersonal function describing the relationships between participants. It is the insertion of speakers' own attitudes and evaluations about the events and to establish a relationship between the speakers and the audience. (3) The textual function of cohesion and coherence in texts. It is a basic tool that allows language users to produce understandable texts with their listeners (Zienkowski et al., 2011).

\subsection{Sociocultural approach}

This approach is led by Norman Fairclough who contributes in the CDA raising of consciousness of exploitative social relations through an emphasis upon language. Fairclough's analytical approach assumed that language helps creating change, and can be used to change behavior allowing the language becoming a power tool. According to Chouliaraki and Fairclough, CDA brings social science and linguistics together within a single theoretical and analytical 
framework. The linguistic theory referred to here is SFL which has been the foundation for Fairclough's analytical framework. Sociocultural approach has three analytical dimensions which includes text (Speech, writing, images or all of them), discursive practice (production of texts, analysis takes place on text level), and social/sociocultural practice (standards of the society or the organizations, social structures, analysis of norm) (Chouliaraki, \& Fairclough, 1999).

Fairclough urges analysts to focus on these three different dimensions in critical discourse analysis of any discursive event. The analysis of text is suggested to include the study of macro and microstructures of the language produced in a certain discursive event. In this context, the analysis of social practice is the investigation of the discursive event based on event realization at a certain time or sociocultural context. Consideration of both linguistic form and meaning is therefore the analysis of the first dimension, text. Fairclough's text analysis consists basically of four main parts: vocabulary, grammar, cohesion, and text structure. The second dimension of the suggested analytical framework is the discourse practice which realizes the analysis of the processes of text production, interpretation, distribution, and consumption. The discourse practice is keen on the analysis of how people produce and interpret texts, and their relation to the orders of discourse: it is the analysis of sociocognitive aspects of text production and interpretation. The third dimension, social practice, includes investigation in different levels of society: from the most localized to institutional or even wider societal contexts. (Heberle, 2000)

\subsection{The United States ideological/political system, Trump, Sanders, and Twitter}

The United States is governed by a presidential system and presidents are elected through an Electoral College every 4 years by the citizens of the US. The senators and House representatives (parliamentarians in a European sense) are elected directly by the people. The political system is structured by a two-party-system where democrats are represented by progressive values and republicans emphasize the conservative value system. Before each election primary caucuses are held within each party to determine the presidential candidates. In the election in 2016 primary caucuses, the political outsider, reality show celebrity and billionaire, Donald Trump Donald won the primaries and run as a presidential candidate for the Republican Party and ultimately won the election.

Trump has been using right-wing populist discourses both throughout the election campaign and during his presidency of the last three years. Both in his speeches and social media communications, Trump has utilized a rather informal language. His cruel anti-immigrant discourse and relatively simple solution to the problems has gain attention from the US rightwing and contributed to his popularity. He has utilized Twitter as an effective instrument of power politics and has fired his cabinet members on the twitter statements. He has been criticized widely for his controversial statements about immigrants, women, African Americans and the disabled and his inaccurate statements. He in response criticized media extensively for his coverage and representation. He has been using twitter very generously to express his views regarding the US media. Rhetoric continued throughout his campaign, and he used Twitter as a primary tool to communicate with the people. Furthermore, Trump continuously drew attention to himself with controversial statements about immigrants, women, and the disabled, just to 
name a few. As President, he has continued to tweet in his particular communication style and has employed Twitter as an instrument of power politics.

Bernie Sanders described himself as a democratic socialist and progressive. Sanders political views on domestic policy can best be describes as supportive of the labor rights, universal and single-payer healthcare, paid parental leave, and tuition-free higher education. He supports reducing military spending, pursuing more diplomacy and international cooperation in international policy along with an increased emphasis on environmental concerns. Sanders served as a U.S. Representative for 16 years from 1990 to 2006 . He elected U.S. Senate from Vermont in 2006 and reelected since then. In April 2015 Sanders declared his candidacy for the 2016 Democratic nomination for President of the United States. He lost to Hillary Clinton with a smaller margin (43\% vs 55\%). As continuation of his "political revolution" Sanders announced a second presidential campaign in February 2019 for the Democratic Party candidacy for the 2020 US presidential election. Bernie Sanders is a long term critics of the corporate campaign donations and has been criticizing US media for serving companies' interests. Similar to Donald Trump, Bernie Sanders also utilizes Twitter as an effective tool to reach to a wider community. He also expresses his views regarding the media on Twitter.

\section{Material and Method}

\subsection{Data collection and analysis}

Trump has been using twitter extensively and there is a wealth of media related tweets. Working from the most recent tweets and collecting retrospectively a total of 445 media related tweets gathered from his personal Twitter account, @realDonaldTrump between 2015 and 2019. An analogous procedure was employed to collect tweets from Bernie Sanders public twitter accounts $@$ BernieSanders and @SanSanders. A total of 50 tweets were manually collected from 2015 to 2019. Because of the fact that President Trump tweeted overwhelmingly higher number of tweets (445) regarding the media compare to Sanders, Trump's tweets were subsampled to have a balanced number (50 tweets from each). To accomplish that, all the tweets from Donald Trump were subjected to a random sampling using Microsoft Office Excel randomization function and 50 tweets were randomly selected. For Bernie Sanders however, all 50 tweets in the corresponding dates we are collecting for comparison and further analysis. Text level of the tweets was analyzed by the method of quantitative content analysis. Socio-cultural approach of Critical Discourse Analysis (CDA) was used to delineate the message expressed from both politicians. The linguistic theory referred to here is systemic functional linguists (SFL) which has been the foundation for Fairclough's analytical framework. The media related tweets were coded for analytical dimensions framed by Fairclough and then analyzed in terms of the text, discursive strategies, and social practices. 


\section{Findings}

\subsection{Donald Trump}

"The Fake News Media is going Crazy! They are suffering a major "breakdown," have ZERO credibility or respect, $\mathcal{E}$ must be thinking about going legit. I have learned to live with Fake News, which has never been more corrupt than it is right now. Someday, I will tell you the secret!" (Mar $28,2019)$

He implies that he knows everything. It is classic rightwing discourse of the Godsend image (Wodak 1989).

"I think this is probably the most consequential media screw up of the last 25 to 50 years. It is difficult to comprehend or overstate the damage that the media did to the Country, to their own reputation or to the Constitution. An absolute catastrophe" Sean Davis @TuckerCarlson." (Mar 26, 2019)

"The Fake News Media has NEVER been more Dishonest or Corrupt than it is right now. There has never been a time like this in American History. Very exciting but also, very sad! Fake News is the absolute Enemy of the People and our Country itself!" (Mar 19, 2019)

"...said was a total lie, but Fake Media won't show it. I am an innocent man being persecuted by some very bad, conflicted $\mathcal{E}$ corrupt people in a Witch Hunt that is illegal $\mathcal{E}$ should never have been allowed to start - And only because I won the Election! Despite this, great success!" (Mar 3, 2019)

The common point on all three aforementioned messages on the text level is what Trump thinks that media being dishonest fake and corrupt. He blames it damaging its own people and country and attacking himself on some issues although he is innocent.

“THE RIGGED AND CORRUPT MEDIA IS THE ENEMY OF THE PEOPLE!" (Feb 17, 2019)

In some of the preceding and following tweets, he also capitalizes some words. Here, he capitalized the entire tweet to get the attention and underline his message.

"The Mainstream Media has NEVER been more dishonest than it is now. NBC and MSNBC are going Crazy. They report stories, purposely, the exact opposite of the facts. They are truly the Opposition Party working with the Dems. May even be worse than Fake News CNN, if that is possible!" (Jan 9, 2019)

"The Fake News Media in our Country is the real Opposition Party. It is truly the Enemy of the People! We must bring honesty back to journalism and reporting!" (Jan 7, 2019) 
"With all of the success that our Country is having, including the just released jobs numbers which are off the charts, the Fake News $\mathcal{E}$ totally dishonest Media concerning me and my presidency has never been worse. Many have become crazed lunatics who have given up on the TRUTH!" (Jan 7, 2019)

"The White House is running very smoothly and the results for our Nation are obviously very good. We are the envy of the world. But anytime I even think about making changes, the FAKE NEWS MEDIA goes crazy, always seeking to make us look as bad as possible! Very dishonest!" (Nov 15, 2018)

Firing the former Secretary of State, Rex Tillerson, over a tweet and appointing Mike Pompeo stimulated a massive discussion in media as expected. In addition, he has been appointing very controversial figures to various critical positions such as Supreme Court and that has been in the center of media attention. When the appointment criticism is intensified, he chooses the tweets similar to the one above to deflect the need to justify the appointments. His message "But anytime I even think about making changes, the FAKE NEWS MEDIA goes crazy" implies that the media is categorically against the changes and the critics are neither legitimate nor case specific.

"Those that worked with me in this incredible Midterm Election, embracing certain policies and principles, did very well. Those that did not, say goodbye! Yesterday was such a very Big Win, and all under the pressure of a Nasty and Hostile Media!" (Nov 7, 2018)

President Trump responds to the political criticism from the media outlets during his election campaign. Instead of even legitimize the critics he attacks the media as 'Nasty and Hostile Media!'

"Check out tweets from last two days. I refer to Fake News Media when mentioning Enemy of the People - but dishonest reporters use only the word "Media." The people of our Great Country are angry and disillusioned at receiving so much Fake News. They get it, and fully understand!" (Oct $29,2018)$

"CNN and others in the Fake News Business keep purposely and inaccurately reporting that I said the "Media is the Enemy of the People." Wrong! I said that the "Fake News (Media) is the Enemy of the People," a very big difference. When you give out false information - not good!" (Oct 29, 2018)

The last two tweets indicate that he is actively engaging his critics in the conventional media outlets and uses a language that attack them instead of responding them. He also directly uses the name of media outlets. e.g. "CNN and others". 
Table 1: The choice of phrases and sentences President Donald Trump used in his tweets

\begin{tabular}{|l|l|}
\hline Dishonest, not being honest, & They are wrong! \\
\hline Enemy of the People! & Catastrophic Media Failure \\
\hline When will this very expensive Witch Hunt Hoax ever end? & Purposely false \\
\hline Nasty and hostile media! & hatred and unfairness of this.... flunky \\
\hline Despite the horrible Witch Hunt and the dishonest media! & Mainstream Fake Media hates this (success story) \\
\hline $\begin{array}{l}\text { If I stayed in Endless Wars forever, they would still be } \\
\text { unhappy! }\end{array}$ & may be the most dishonest of the media outlets \\
\hline $\begin{array}{l}\text { The Fake News Media has NEVER been more Dishonest or } \\
\text { Corrupt than it is right now }\end{array}$ & We must bring honesty back to journalism and reporting! \\
\hline The Media is not giving us credit & The Fake News Media is going Crazy! \\
\hline the most consequential media screw up & An absolute catastrophe \\
\hline Biggest story that Fake Media doesn't want to follow! & will never be reported correctly by the Fake News Media \\
\hline The fake news media has it, purposely, so wrong! & other Fake Media to show how bad (cruel) we are \\
\hline
\end{tabular}

Table 1 demonstrates the phrases and sentences Donald Trump used in his tweets most of which have negative associations with media. While some of his tweets reflects how Trump is criticizing media to not to show his success or not reporting accurately (e.g. not being honest and accurate, posting false information, lying), he insists that the media tries to show how bad (cruel) he is and never gives him a credit for his achievements. He utters that all the "Fake News Media" wants to talk about is his mistakes. He rarely appreciates some specific (media) channels and press.

Table 2: Repetitive words and phrases that President Donald Trump used for defining media along with the frequency

\begin{tabular}{|l|c|}
\hline Repetitive words & Frequency \\
\hline Fake news/ Fake news media/ Fake universe & 47 \\
\hline $\begin{array}{l}\text { Dishonest, not being honest, inaccurate, never report correctly, false information, wrong, lies, } \\
\text { shame, inaccurately reporting }\end{array}$ & 18 \\
\hline Nasty, illegal, hostile, rigged, flunky & 8 \\
\hline $\begin{array}{l}\text { (Media) won't show, wants to talk about, doesn't report, media ignores, not giving us credit, } \\
\text { doesn't want to follow }\end{array}$ & 8 \\
\hline The enemy of the people \& country & 7 \\
\hline Crazy, screw up, crazed lunatics & 7 \\
\hline Bad & 7 \\
\hline Witch hunt & 4 \\
\hline Hatred, hate and unfairness & 4 \\
\hline Corrupt & 4 \\
\hline Zero credibility and respect & 3 \\
\hline Catastrophic & 2 \\
\hline Hoax & 1 \\
\hline
\end{tabular}

Table 2 indicates repetitive words and phrases along with the frequencies that Trump used for defining media. The most of the word groups have either negations or contains negative adjectives. In order to convey how he feels, Trump uses strong adjectives to define media. While he uses the fake news/ media (universe) the most (47 times), catastrophic (2 times) and hoax (1 time) are the words used the least among randomly selected tweets. The adjectives and adverbs such as dishonest, not being honest, inaccurate, never report correctly, false information, wrong, inaccurately 
reporting were used high in number (18 times) to show how some media is biased and not trustworthy. Nasty, illegal, hostile, rigged, and flunky are used (8 times) equal times with the structures as (Media) won't show, wants to talk about, doesn't report, media ignores, not giving us credit, doesn't want to follow. Bad, witch hunt, hatred adjectives, and corrupt are used several times (4 times) out of 50 tweets. Another reduced usage of word is zero credibility and respect (3 times).

\subsection{Bernie Sanders}

"We're going to do something today that the media doesn't often do. We're going to talk about why it is that 3 families own almost as much wealth as the bottom half of America. Join our town hall in Londonderry, New Hampshire." (29 May 2019)

By aforementioned tweet, it is apparent that Bernie Sanders criticizes media because he thinks the media fails to fulfill one of its fundamental missions of emphasizing "real news" and inform folks about realities such as income distribution.

"We're still a little short of our end-of-quarter fundraising goals. But if we make it, it will send an unmistakable message to the media and our opponents about the strength of our campaign. Push us over the finish line with your contribution by midnight." (30 Sept 2019)

In this message, he encourages his followers to raise a little more money for fundraising and send message to the media and their opponents articulating two together binding with connector "and".

"At a time when climate change is already causing devastating harm, the mainstream media coverage of climate change actually decreased by 45\% in 2018. That is a disgrace" (Mar 12, 2019)

Sanders is warning the media for not prioritizing the real significant issues such as climate change and the costs and results of it. Contrary to Trump, he uses accurate numbers to justify his critics.

"It appears Mr. Trump, who attacks media that makes critical remarks about him as "fake news" doesn't understand what democracy is about." (Feb 20, 2017)

"When Donald Trump attacks the media as "fake news" what he is doing is trying to move our country in an authoritarian direction." (Feb 12, 2017)

In two previous tweets, we could realize that although Bernie Sanders criticize media to some extent, he also defends medias role in a democracy and stands with the media while making news and manifesting critical remarks about any politician. 
"I think politicians and the media often underestimate the intelligence of Americans and their desire to learn about what's going on." (Nov 22, 2016)

"It's not acceptable that a handful of billionaires is now controlling our political process and the corporate media refuse to talk about it." (Jul 8, 2016)

"We have gotta ask the media if they think that as a nation, maybe the American people are entitled to hear real discussions on real issues." (May 8, 2016)

As in most of his tweets, Sanders directs the attention to "real discussions" and "important issues" that people should think about rather than the artificial news.

"The corporate media and establishment keep counting us out, but we keep winning by large margins. Keep us going: http://bernie.to/WeWon" (Apr 6, 2016)

He thinks that the media purposely shows that Bernie Sanders and his voters are behind.

"When Donald Trump not only attacks the media as "fake news," but glorifies physical attacks on journalists, what he is doing is trying to move our country in an authoritarian direction." (Oct 21, 2018)

"This is how we fight back against the corporate attacks on journalism. We will do everything we can to support media workers' efforts to form unions and collectively bargain. Congratulations to the @azrepublicguild!" (12 Oct 2019)

Although Sanders criticize media every once in a while, he does not approve the way Trump attacks the media, he also criticizes how trump treats the media and calls his followers for supporting, and defending journalism against the corporate attacks.

"In a nation where corporate media defines what's "acceptable", voter turnout lags behind almost every major nation and billionaires can buy elections, our job is to open the doors of democracy and elect candidates who support economic, social, racial and environmental justice." (Jul 2, 2018)

Sanders defines the real job as what people should do as electing candidates who could be beneficial to the society in every aspect such as economy, social, racial and environmentally. He claims that the billionaires should not buy the elections and media should not misdirect the public.

"At a time when this world faces so many problems, the corporate media will talk about everything in the world except important issues." (Aug 9, 2016) 
Bernie Sanders thinks that biased media refuses to focus on the real problems people face and important issues, so he tries to draw attention to these issues.

"Despite what the media tells you, politics is not a soap opera. Politics is about coming together to improve the lives of all." (Jul 17, 2016)

"At a time when media looks at politics like a baseball game, will the serious issues be discussed tonight? Let's see. \#DebateWithBernie." (Sep 17, 2015)

Sanders disagrees with the media attitude toward the politics and their choice of prominence of news or reflects the role of politics and he criticizes how media treats politicians by using the words "soap opera characters" and saying "they are looking at politics like baseball game."

"We're not gonna allow the corporate media to define the issues for us. It's up to us to talk about reality in America." (Jun 25, 2016)

"Every day, the corporate-controlled media and the political establishment tell us: think small. Well, you know what? We're gonna think big." (Jun 1, 2016)

"Corporate media wants you to think small, to think that we cannot provide education and healthcare for all. I strongly disagree!" (May 23, 2016)

Sanders uses a strong language to pass his message regarding the possibility and plans of free healthcare, and free college (university) education. He also criticizes the default media position toward free and publicly funded education and health care.

"The corporate media counted us out. The pollsters said we were way behind. But we won. Thank you, Michigan." (Mar 9, 2016)

"ABC News spent 81 minutes on Donald Trump and only 20 seconds on our campaign. You read that right. Seconds." (Dec 12, 2015)

He warns his people to be aware of the situation that some TV channels have an agenda to overlook the progressive success in terms of getting the message delivered to a wider public. He also draws attention to the unfair media coverage when progressives were compared to the conservative right wing.

"It is not just income and wealth inequality. It is not only corporate control over the media. The real issue is: who is gonna stand up to them?" (Nov 12, 2015) 
"Thousands of people die every single year because they don't have health insurance. But the media doesn't cover that. That ain't big news." (Sep 24, 2015)

Sanders emphasizes on the inequality of income and wealth along with the usage of media to sustain the contemporary economic model in preceding tweets and invites people to stand up to them.

"Sheldon Adelson is spending unbelievable sums of money, not just on elections, but for control of our media too." (Dec 17, 2015)

In the abovementioned tweet, Sanders tries to prove that he is always telling by "controlled media."

Table 3: Phrases and sentences that Senator Bernie Sanders used for defining media

\begin{tabular}{|l|l|}
\hline Media wants/tells us to think small & Media treats politics like a soap opera character \\
\hline Corporate greed in media continues to threaten jobs & Real discussions/real issues/reality, most important \\
\hline Corporate media refuses to talk about it & This is shameful! \\
\hline This is disgrace! & Media is controlled \\
\hline if media think as a nation & That isn't big news! \\
\hline Media can't define the issues for us & The people are sick and tired of media status quo \\
\hline Media defines what is acceptable candidates & Media will talk anything except important issues. \\
\hline Media doesn't cover that (health insurance) & Media underestimates the intelligence of Americans \\
\hline Media doesn't see the politics serious & Who is going to stand up to them? \\
\hline Corruption of corporate elites & Media doesn't often do that (talking about reality) \\
\hline Whether the media likes it or not & Media is diverting our attention away \\
\hline Media are missing & Unwillingness to talk about real issues \\
\hline
\end{tabular}

Table 3 shows the sentences or phrases that senator Sanders used to define media on Twitter. He generally points out that media is controlled by big corporates (corporate elites). He also frequently pointed that as a reason why the media does not discuss real issues and the most important problems people and/or country face with the phrase such as "unwillingness to talk about real issues." Sanders thinks that the media diverts people's attention away while frequently expressing that "Media is diverting our attention away." He also criticizes the way media treats politicians ("like soap opera characters") and how people are "sick and tired of media status quo".

Table 4: Frequency of repetitive words and phrases that Senator Bernie Sanders used to define media

\begin{tabular}{|l|c|}
\hline Repetitive words & Frequency \\
\hline The corporate (media) & 19 \\
\hline $\begin{array}{l}\text { Real issues, reality in America, real discussions, serious issues, most important issues, aint big } \\
\text { news, many problems }\end{array}$ & 9 \\
\hline Media and political establishment & 6 \\
\hline Establishment media & 4 \\
\hline Corporate-controlled media & 3 \\
\hline They refuse (to tell what is going on) & 2 \\
\hline Media tells/wants (us to think small) & 2 \\
\hline
\end{tabular}


OF PRESIDENT DONALD TRUMP AND SENATOR BERNIE SANDERS

\begin{tabular}{|l|c|}
\hline \hline Mainstream media & 2 \\
\hline Independent news/ free press & 2 \\
\hline Corporate/ media elites & 2 \\
\hline The major media & 1 \\
\hline Media consolidation & 1 \\
\hline Media bias & 1 \\
\hline
\end{tabular}

Table 4 indicates frequency of repetitive words and phrases which Sanders used to define media. He used the corporate media (19 times) the most frequently followed by phrases such as real issues, reality in America, real discussions, serious issues, most important issues, aint big news, and many problems (9 times) since he thinks that media never discusses the most important issues such as low wage, health insurance expenses, and free college education. Establishment (6 times) is the third most used word by Sanders as in media establishment or political establishment and establishment media are other words Sanders used often (6 times). Corporate-controlled media (3 times), corporate/media elites (2 times), and media consolidation (1 times), the major media (1 times), and mainstream media (2 times) are similar phrases Sanders used with an intention to convey that media unfortunately is controlled by "some powers".

An overall comparison of both politicians in terms of structure and writing styles revealed that Trump's messages are different than Sanders as Trump uses many exclamation marks and Capital letters to emphasize and show his feelings about events. Besides Trump relative writes longer tweets, sanders share shorter ones.

\section{Discussion and Conclusion}

The social media microblogging site, Twitter, has transformed into an efficient tool to disseminate political messages without dependency to the conventional media. In this way, the platform offers an invaluable opportunity for criticizing establishment (mainstream media in this context) which both President Trump and Senator Sanders are inclined to do, albeit in different angles.

Based on the analysis of President Trump's tweets, it can be concluded that he uses a simple and direct language to express his message with common spoken words. He delivers his messages in a brief and polarizing way that has been a common strategy of right-wing populist discourse. President Trump also reinforces his message using capitalization and exclamations very often (Ott, 2017). He also distances himself from the bureaucracy by using his personal user account even after being elected as the president. This helps his image of legitimatizing himself as representative of people. He created an image of himself in relation to the people: the leader who protects the nation and homeland from the dangerous "Other". He creates an evil image of media that is purposefully deceiving the American people and the American homeland. He instantaneously exposes himself as "the one" who reveal the 'true news' to the American community by referring to the media as "FAKE NEWS" and "corrupt". The analyses in the present study suggest that President Trump employs such a discourse to handle media critics in a new form by demonization of the main media outlets in US. 
Senator Sanders on the other hand uses a whole different set of words to criticize media. He commonly uses the word "corporate media" to delineate the lack of media attention to the "real issues". Unlike President Trump, Senator Sanders lists a number of "real discussions on real issues" that he calls the media attention. Those are "health insurance, education, climate change, and billionaires buy elections". He also criticizes media on the ground that they are not fair in the coverage of his campaign. Similar to President Trump, Sanders also distances himself from the bureaucracy and establishment. He, too, creates an evil image of media that is purposefully deceiving the American people and the American homeland by avoiding addressing the real issues and focusing on the corporate agenda. One interesting point is that despite his critics of media, Sanders also defends media after Trumps excessive and heavy critics through social media. One other fundamental difference in Sanders' tweets is that he uses accurate numbers and percentages to raise a critic regarding to the media coverage which is virtually absent in Trump's messages.

Social norms, particularly for the left wing, have moved to an environmentally friendly discourse/lifestyle. Bernie Sanders emphasizes that the media coverage is significantly distinct from that norm. On the other hand, the right wing public largely believes that climate change is a hoax and not important for their social norm and political agenda. The free healthcare and higher education is also deemed as an unnecessary discussion since it is largely regarded as parasitical situation by rightwing social norm. Therefore, it is not surprising that this discourse does not appear as a legitimate discussion in Donald Trump's tweets.

Both politicians therefore enjoy the technological and cost-free advantage of the communicating their message to the broader audience using Twitter. They both enjoy the freedom of transferring their critic of the mainstream media using social media. Although both politicians have criticized media, the analyses indicated that the motivation, the language, and the social content of their criticisms differ fundamentally.

\section{About the Author}

Hülya Ünsal Şakiroğlu is an instructor at School of Foreign Languages at Kafkas University, Kars where she has been teaching English as foreign language for more than eight years. She obtained her BS degree from English Language Teaching Department at Cukurova University in 2003. After graduation she lived in United States for seven years and worked as an instructor to English to young children and immigrant women. She obtained MS degree at Curriculum and Instruction in Faculty of Education at Kafkas University and currently pursuing PhD at Department of English Linguistics in Faculty of Letters at Hacettepe University, Ankara, Turkey.

\section{References}

Arsenault, Amelia H., and Manuel Castells. 2008. "The Structure and Dynamics of Global MultiMedia Business Networks." International Journal of Communication 2: 43.

Bennett, W. Lance. 2004. "Global Media and Politics: Transnational Communication Regimes and Civic Cultures." Annu. Rev. Polit. Sci. 7: 125-148. 
Burchell, Jon, and Joanne Cook. 2006. "Confronting the 'Corporate Citizen' Shaping the Discourse of Corporate Social Responsibility." International Journal of Sociology and Social Policy 26 (3/4): 121-137.

Chilton, Paul. 2004. Analysing Political Discourse: Theory and Practice. routledge.

Ekman, Mattias, and Andreas Widholm. 2015. "Politicians as Media Producers: Current Trajectories in the Relation between Journalists and Politicians in the Age of Social Media." Journalism Practice 9 (1): 78-91.

Fang, Zhihui. 2005. "Scientific Literacy: A Systemic Functional Linguistics Perspective." Science Education 89 (2): 335-47. https://doi.org/10.1002/sce.20050.

Gee, James Paul, and Michael Handford, eds. 2012. The Routledge Handbook of Discourse Analysis. Routledge Handbooks in Applied Linguistics. London ; New York: Routledge.

Grant, Will J., Brenda Moon, and Janie Busby Grant. 2010. “Digital Dialogue? Australian Politicians' Use of the Social Network Tool Twitter." Australian Journal of Political Science 45 (4): 579-604.

Heberle, Viviane. 2000. "Critical Reading: Integrating Principles of Critical Discourse Analysis and Gender Studies." Ilha Do Desterro A Journal of English Language, Literatures in English and Cultural Studies, no. 38: 115-138.

Koopmans, Ruud, and Paul Statham. 1999. "Political Claims Analysis: Integrating Protest Event and Political Discourse Approaches." Mobilization: An International Quarterly 4 (2): 203221.

Larsson, Anders O., and Bente Kalsnes. 2014. "“Of Course We Are on Facebook': Use and NonUse of Social Media among Swedish and Norwegian Politicians." European Journal of Communication 29 (6): 653-667.

O'keeffe, Anne. 2011. "Media and Discourse Analysis."

Ott, Brian L. 2017. "The Age of Twitter: Donald J. Trump and the Politics of Debasement." Critical Studies in Media Communication 34 (1): 59-68.

Schiffrin, Deborah, Deborah Tannen, and Heidi E Hamilton. n.d. "The Handbook of Discourse Analysis," 874.

Stieglitz, Stefan, and Linh Dang-Xuan. 2013. "Social Media and Political Communication: A Social Media Analytics Framework." Social Network Analysis and Mining 3 (4): 1277-1291.

Van Dijk, Teun A. 1993. "Principles of Critical Discourse Analysis." Discourse E Society 4 (2): 249_ 283.

- - . 2001. "Critical Discourse Analysis." The Handbook of Discourse Analysis 18: 352-371.

Wigand, Rolf T., Jerry D. Wood, and Dinah M. Mande. 2010. "Taming the Social Network Jungle: From Web 2.0 to Social Media." In AMCIS, 416.

Wilson, John. "20 Political Discourse." The handbook of discourse analysis 18 (2003): 398.

Wodak, Ruth. 1989. Language, Power and Ideology: Studies in Political Discourse. Vol. 7. John Benjamins Publishing Company.

- - - . 2015. The Politics of Fear: What Right-Wing Populist Discourses Mean. Sage.

Zienkowski, Edited Jan, Jan-ola Östman, Jef Verschueren, Jef Verschueren, Jan-ola Östman, Janola Östman, Jef Verschueren, Jan-ola Östman, and Jef Verschueren. n.d. Discursive Pragmatics Edited By. 

or adapt the article content, providing a proper, prominent and unambiguous attribution to the authors in a manner that makes clear that the materials are being reused under permission of a Creative Commons License. Views, opinions and conclusions expressed in this research article are views, opinions and conclusions of the author(s). and European Journal of Literature, Language and Linguistics Studies shall not be responsible or answerable for any loss, damage or liability caused in relation to/arising out of conflicts of interest, copyright violations and inappropriate or inaccurate use of any kind content related or integrated into the research work. All the published works are meeting the Open Access Publishing requirements and can be freely accessed, shared, modified, distributed and used in educational, commercial and non-commercial purposes under a Creative Commons Attribution 4.0 International License (CC BY 4.0). 